\title{
Inherent Conflicts Of Interest In The Accounting Profession
}

Curtis E. Clements, Abilene Christian University, USA John D. Neill, Abilene Christian University, USA

O. Scott Stovall, Abilene Christian University, USA

\begin{abstract}
In this paper, we critically examine three situations in the accounting/auditing profession in which conflicts of interest arise. Specifically, we describe conflicts of interest that occur (1) because audit fees are paid by the very companies being audited, (2) due to the tension built into accountants' codes of professional ethics between the responsibility to maintain client confidentiality and the need to serve the public trust, and (3) because of most auditors' perspective of who is their primary client. Based on our analysis, we conclude that these three inherent conflicts of interest, in the absence of some unforeseen revolutionary changes, are likely to persist within the auditing profession. We also conclude that attempts to mitigate some of these conflicts of interest through the Sarbanes-Oxley legislation have only been moderately successful. We therefore propose that audit professionals must learn to identify and manage the conflicts of interest that will likely remain a part of the profession for the indefinite future.
\end{abstract}

Keywords: Accounting Profession; Audit Committee; Client Confidentiality; Conflicts of Interest

\section{INTRODUCTION}

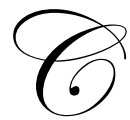

onflicts of interest, or at least the potential for such conflicts to exist, are a reality in virtually all walks of life. As an example, consider an untenured professor who must assign a grade to the son/daughter of the university president or one of the university's largest donors. It is plausible that the perceived ramifications of assigning a deserved failing grade in that situation might influence the professor's judgment. As another example, a conflict of interest would exist for a college football referee who was a graduate of one of the competing universities. More indirectly, a conflict of interest might also exist if one of the teams was from his home state or from his favorite conference, region of the country, etc. Still other examples would include a physician who receives financial considerations, even if it is only in the form of free samples, from drug companies in the hope that the physician will prescribe that company's medications, or a cashier who finds that his/her best friend is next in line to pay and requests that the cashier overlook certain items in the checkout process.

Even though conflicts of interest are clearly evident in the previous examples, it does not necessarily follow that such conflicts will result in unethical behavior. The actors in the above examples might not be unduly influenced by the potential conflict of interest and therefore might behave ethically even in the face of the conflict. Alternatively, the person facing the conflict of interest might make an unethical decision, sometimes without even realizing how much their decision was influenced by competing factors.

A necessary step in preventing unethical behavior in such situations is realizing the potential for conflicts of interest to exist. Only then can safeguards be put into place in an attempt to mitigate the conflicts. For example, collegiate athletic conferences realize that referees might have a conflict if their favorite team is competing and therefore conferences often have rules that prohibit officials who are alumni of one of the competing universities or who live in the city where one of the competing teams is located from officiating a game. Retail establishments recognize that a cashier might be tempted to not charge for all the items in a family member's or friend's basket. They therefore often place an employee at the exit to verify that the number of items charged on a customer's receipt matches the number of items in the customer's basket. In fact, organizations such as these initiate and maintain 
internal control structures to mitigate the potential effect of conflicts of interest on organizational operations and resources.

As the above examples illustrate, conflicts of interest are possible in many different areas of life. In the current paper, we examine the specific situations of conflicts of interest that arise in the accounting profession. We utilize the practice of auditing in most of our examples. The purpose of this paper is to critically examine three specific situations in the accounting profession in which conflicts of interest are inherent. Included in our examination will be a discussion of the problems that may result from such conflicts of interests as well as some proposed solutions. We also provide a number of suggestions for future research in these areas.

\section{BACKGROUND AND MOTIVATION}

At the outset, let us define what we mean by conflict of interest. We employ Davis' (2005, p. 4) definition, which states that:

A conflict of interest is a situation in which some person $P$ (whether an individual or corporate body) stands in a certain relation to one or more decisions. On the standard view, $P$ has a conflict of interest if, and only if, 1) $P$ is in a relationship with another requiring $P$ to exercise judgment in the other's behalf and 2) $P$ has a (special) interest tending to interfere with the proper exercise of judgment in that relationship.

In terms of the accounting/auditing profession, $\mathrm{P}$ could be either an individual auditor or an auditing firm. Individual auditors have many constituents to whom they are accountable, including the company whose records they are auditing, that company's audit committee and shareholders, and the audit firm that employs the auditor. However, auditors' ultimate responsibility is to report on the fairness of a company's financial statements and thereby uphold the public trust. Therefore, auditors would have a conflict of interest any time they have a special interest that might interfere with protecting the public trust. In the following sections, we will describe three situations where auditors might put the interests of others (e.g., themselves and/or client company management) above the public interest.

\section{CONFLICT THAT ARISES BECAUSE AUDIT FEES ARE PAID BY MANAGEMENT}

The first conflict of interest in the audit profession that we will describe results from the long-standing business practice in which the company being audited pays for the audit. While alternative systems have been proposed, it remains standard practice for companies to pay auditors for attesting to the fairness of their financial statements. This conflict, while hardly acknowledged in practice, has been described in numerous prior research efforts. For example, Moore et al. (2006), Nelson (2006), and Bazerman et al. (2006) examine whether recent reforms in the accounting profession are sufficient to overcome the inherent conflicts in the profession, many of which are due to the fact that management hires and pays the auditors. In addition, Bazerman et al. (1997), Damman (2003), Dilworth (1994), and Boyd (2004) each question the independence of auditors in light of the fact that the line between the supposed independent and "professionally skeptical" auditor and company management often becomes blurred.

Even if an auditor is independent in fact, it is hard to imagine how an audit firm could maintain the appearance of independence and thereby preserve the public trust when the very companies that they audit supply the primary source of their revenues. Three potential problems caused by this conflict of interest are: (1) without the appearance of independence, the public loses faith in the quality of the financial reporting process, (2) auditors would be tempted to give in to management on important accounting issues since the company being audited is responsible for paying the audit fees, and (3) in the name of "client service," auditors might provide guidance on accounting issues to managers of companies they audit to such an extent that they are in effect "auditing their own work." While none of these conditions automatically preclude auditors from engaging in ethical behavior, in each case conditions are present for unethical behavior to occur and the appearance of independence is suspect.

Within the last decade, regulators have attempted to minimize this potential conflict. In particular, under the Sarbanes-Oxley Act, an audit committee comprised of independent members of the board of directors is 
responsible for hiring/firing the company's auditors and negotiating the audit fees. However, the new regulations will only be effective in reducing conflicts of interest if the audit committee is truly independent of management. If the audit committee is really just an extension of management, then the long-standing conflict of interest that results from audited companies paying auditors still remains.

In addition to the recent regulatory attempts to mitigate this conflict of interest, another possible solution to this long-standing problem would be to change the way that auditors are paid. For example, at one time it was proposed to have the major stock exchanges pay the audit fees for listed companies. The stock exchanges would then increase the fee that they charge to listed companies. Another option would be for audit firms to be assigned to audits by some governmental agency that is also responsible for paying the audit fees.

We have some suggestions for future research in this area. For example, an avenue for additional research would be to examine the extent to which audit committees are actually independent of management. Such an examination could involve conducting a large-scale survey of audit committee members and upper management of audited companies. Alternatively, one could assess the independence of audit committee members by employing detailed interviews of a relatively small number of audit committee members. Hoffman et al. (2008a, 2008b) used such a methodology to assess the independence of corporate chief ethics officers and mutual fund compliance officers.

\section{CLIENT CONFIDENTIALITY VERSUS SERVING THE PUBLIC TRUST}

Our second example of a conflict of interest in the accounting/auditing profession is due to seemingly conflicting requirements in the accounting profession's code of ethics. Both the American Institute of Certified Public Accountants' (AICPA) Code of Professional Conduct and the International Federation of Accountants' Code of Ethics emphasize the importance of maintaining client confidentiality, while at the same time mandating that members of the accounting profession must serve the public trust. While such ethical goals may often be congruent, it is not difficult to imagine situations in which these goals may create a conflict of interest. Let us suppose for example, that in the course of assessing the adequacy of a company's internal controls, auditors discover a weakness in the company's controls over inventory. Investors, tax authorities, vendors, and customers would benefit by knowing about such an internal control weakness. In addition, Sarbanes-Oxley requires the auditor to disclose all material weaknesses in internal control. However, the company's management would have a vested interest in not revealing this internal control weakness and might argue that the weakness is immaterial and therefore does not have to be disclosed by the auditor.

As another example, an auditor might determine that the company being audited is in dire financial condition and may not be able to continue as a "going concern." The public trust would be served by reporting this concern as part of the audit report. However, company management might try to convince the auditor not to report the going concern problem since disclosing the auditor's concerns about the ability of the company to continue is sometimes viewed as a "self-fulfilling prophecy." In other words, management may not want to disclose this going concern problem in fear that customers might take their business elsewhere, creditors might demand immediate payment of amounts owed, suppliers might be reluctant to provide inventory on credit, etc. In some situations, the auditor might also prefer to keep a possible going concern problem quiet. If the receipt of a going concern audit opinion is indeed a self-fulfilling prophecy, it would also be detrimental to the audit firm to render a going concern opinion since the audited company would ultimately fail, which would result in the auditor suffering a reduction in audit fees.

In both of the cases described above, serving the public trust would require the auditor to reveal information that the client would prefer to remain confidential. The potential problem that arises in these cases is that the accountant/auditor might be tempted to put the client's interests above the public interest due to fears of client retribution (i.e., losing the client and the resulting audit and/or consulting fees). A potential solution to this conflict of interest problem would be to reword the code of professional conduct to more specifically address the relationship between client confidentiality and serving the public interest and to stress that when these goals conflict that serving the public trust is paramount. 
Even though client confidentiality is mandated by most codes of conduct in the accounting profession, auditor-client communications are not afforded legal protection. This is in contrast to the longstanding "attorneyclient privilege" in the legal profession. An interesting path for future research in this area would be to examine court cases to determine the extent to which the courts have protected auditor-client communications and/or audit client documents from disclosure due to some sort of "auditor-client privilege."

\section{USE OF THE TERM “CLIENT” TO REFER TO COMPANY MANAGEMENT}

We would argue that the language used by members of the accounting profession itself may be the underlying cause of this third conflict of interest. It is commonplace for auditors to use the word "client" to refer to members of the management team of the company being audited rather than to that company's shareholders, audit committee, or board of directors. It is likely that such language used by members of the accounting/auditing profession, which is a service-based, client-oriented business, contributes to a potential bias toward professional opinions which favor management over other all other constituencies (e.g., the public or company shareholders). In other words, the practice of referring to company management as "the client" in common professional discussion likely reinforces an inherent bias in the profession toward favoring management over shareholders and other interested stakeholders.

In terms of proposed solutions to this conflict of interest, we view this as largely an awareness issue. Auditors, and especially relatively inexperienced auditors, need to be trained and reminded that they are ultimately responsible to company shareholders, board of directors, and the general public rather than to company management. University auditing and accounting ethics courses need to play a role in clarifying for students exactly who the "client" is in the auditing profession. Once in the workplace, audit firm training can also play a role in enhancing awareness on this issue.

There are a number of research opportunities related to this issue. For example, future researchers could conduct a large-scale survey of practicing auditors (at various levels) to determine whom they view as their primary client. Our anecdotal evidence on this issue is that practicing auditors view the client as the company personnel with whom they interact on a daily basis. For example, audit partners would likely view upper management along with the audit committee as their client since they have frequent interactions with those groups. Conversely, junior auditors might view the client as the mid-level accounting and management staff that they see on a regular basis. It is unlikely that many auditors view the general public as their client; however, that is an empirical issue that could be answered by this line of inquiry. A second way to examine this issue would be to conduct detailed interviews with a small sample (say 10 or so) practicing auditors to determine whom they view as their primary client.

\section{INTERVIEW WITH AN AUDIT MANAGER AT AN INTERNATIONAL ACCOUNTING FIRM}

In order to provide some anecdotal evidence on the issues that we have explored in this paper, we interviewed an audit manager at a large, international (i.e., Big-4) accounting firm. At the date of the writing of this paper, this person had been in public accounting for about seven years, with approximately two years at the manager level. Our interviewee is male and is a specialist within the financial services industry. Given his tenure with the auditing firm, he has had significant interaction with upper management and other client company personnel, audit committee members, regulators, and of course personnel within his own firm.

From the outset of our discussion, this auditor recognized that conflicts of interest of the nature that we describe in the paper clearly exist within the auditing profession. He observed that although new ethics rules created by the Sarbanes-Oxley Act require audit committees to "officially" hire/fire the audit firm and approve audit fees, upper management of audited companies often still exert considerable influence on such decisions. Specifically, he noted that although audit committees officially approve audit fees, the fact remains that the funds used to pay the auditors and the approvals of such payments flow through the audited company. It was our interviewee's experience that personnel of the company being audited often inquire, and even at times contest audit fees, even though the supposedly independent audit committee is responsible for approving such fees. Our limited experience with audit committees provides evidence consistent with our interviewee's perception that audited company personnel continue to exert a great deal of influence on audit committees regarding audit fees, auditor changes, and other auditor related decisions, despite legislated efforts to make audit committees more independent. 
Our interviewee provided us additional perspective relating to the conflict of interest that arises because the company being audited pays the auditors. He stated that audit firms, including the one that he works for, emphasize "client service" toward audited companies. Our audit manager noted that while his firm encourages their employees to maintain a healthy amount of professional skepticism in interacting with client company personnel, the firm also strongly encourages their audit staff to deliver a "value-added experience" to audited companies. While our interviewee did not specifically say so, an implication of this client service emphasis is that it is possible that auditors will employ a "the customer is always right" attitude toward the company being audited. As we stated earlier, it is our opinion that this type of attitude is misguided since the ultimate customer of audits is not the audited company, but rather the public that relies on the audited financial statements.

In regards to the conflict of interest that arises because of the tension that auditors sometimes face between preserving client confidentiality and protecting the public trust, our interviewee provided us insight into what seems to be a relatively new phenomenon in which regulators have begun to communicate directly with auditors. Specifically, he mentioned a case involving the now defunct mortgage lender Taylor Bean and Deloitte LLP, who served as their independent auditor. In this case, a financial regulator contacted the audit firm directly when Taylor Bean's regulatory reports were not filed on time. According to Hagerty and Timiraos (2009), after receiving suspicious information from Taylor Bean management as to why their required audited financial statements were not filed on time, regulators contacted Deloitte LLP directly. The audit firm then informed the regulators that (1) representations made by Taylor Bean management as to why their audited financial statements were filed late were misleading and (2) Deloitte LLP had concerns regarding some of Taylor Bean's accounting practices.

In addition to bringing the Taylor Bean case to our attention, our interviewee mentioned that direct contact had occurred between regulators and auditors in his firm and other public accounting firms. Our audit manager noted that with respect to the financial services industry in particular, it is becoming increasingly apparent that auditors may have to default toward public-trust interests over client confidentiality concerns by disclosing information to regulators outside of routine financial reporting structures. If this trend of regulators contacting auditors directly continues, then it will become increasingly more difficult for auditors to uphold the provisions of the accounting profession's code of conduct relating to client confidentiality.

Our audit manager interviewee also addressed the question of who is "the client" in the auditing profession. His perspective, which was based on his own experience and from observing other auditors, is that an auditor generally views the client as the company personnel that he/she interacts with most regularly. Therefore, an auditor's perception of who the client is substantially depends on the auditor's professional level. Specifically, our interviewee's view was that (1) relatively inexperienced audit staff tend to interact with lower to mid-level accountants, (2) audit seniors tend to interact more with upper management, (3) audit managers interact with upper and senior management and have some exposure to audit committee members, and (4) partners interact with senior management and audit committee members, including significant interaction with the audit committee chairperson. Our interviewee therefore presumes that auditors at various professional levels have differing views of who is their client since auditors at various levels interact with different company personnel. However, we find it interesting that the general public would not be viewed as the primary client by any professional level within an auditing firm, even audit partners.

\section{CONCLUSIONS AND IMPLICATIONS}

In this paper, we describe three situations in the accounting/auditing profession in which conflicts of interest are inherent. These conflicts are due to the facts that (1) auditors are paid by the companies they audit, (2) there is a built-in tension in accountants' codes of professional conduct between the necessity of serving the public trust and the responsibility to maintain client confidentiality, and (3) there is a commonplace misuse of the term "client" among practicing accountants. There are a number of conclusions and implications of our analysis.

The first implication is the perhaps obvious observation that conflicts of interest are likely to persist within the auditing profession. The tensions that we have described in this paper, in the absence of some revolutionary changes, are likely to continue. It is our opinion that the attempt to mitigate some of these conflicts of interest through the Sarbanes-Oxley legislation has only been moderately successful. We suggest that educational efforts at 
the university level need to equip accounting students with the skills necessary to identify and manage the conflicts of interest that are inherent within the profession that they are entering. Various conflicts of interest will present themselves to accountants whether they work as external auditors, internal auditors, corporate accountants, or regulators. Also, professional training must help accountants maintain their ability to continually identify and manage conflicts of interest that they encounter in the workplace.

A second implication of our examination is that the accounting profession, along with regulators, legislators, shareholders, and other interested parties may need to discuss and potentially change the way that auditors are paid. Other systems besides the current system where auditors are paid by the very companies they audit have been proposed. While some have argued that public company audits should be nationalized, there are other potential private-market solutions that could be explored.

Based on our analysis, we also conclude that organizations such as the AICPA may need to revise their code of ethics/conduct in light of the evolving landscape of conflicts of interest within the auditing profession. These codes, which require accountants to adhere to professional principles such as client confidentiality while at the same time rhetorically describing accountants' responsibilities to preserve "the public trust," place auditors in precarious positions when their clients' and the public's interests conflict. At a minimum, such accounting organizations should, within their codes, offer some mechanism to help auditors prioritize conflicting interests among the audit profession's constituents.

Finally, we conclude that conflicts of interest within the auditing profession are not inherently bad, but they must be indentified and managed by the auditor. Auditors work in complex environments in which competing interests are typically present. In fact, recent developments such as an emphasis on principles-based accounting standards will increasingly require auditors to use professional judgment when dealing with clients on financial accounting issues. Society would not need professional accountants if all accounting issues could be resolved with obvious, easy answers. Instead, audit firms are paid to make difficult decisions in complex environments. Audit professionals must learn to identify and manage the conflicts of interest that will likely remain a part of the financial reporting and auditing process for the indefinite future.

\section{AUTHOR INFORMATION}

Curtis E. Clements, Ph.D., CPA, is an associate professor of accounting at Abilene Christian University and has published articles in the Journal of Business Ethics, Journal of Accounting and Public Policy, Journal of Information Systems, Internal Auditing, and Strategic Finance. E-mail: curtis.clements@ acu.edu

John D. Neill, Ph.D., CPA, is a professor of accounting at Abilene Christian University and his publications include articles in the Journal of Business Ethics, Corporate Governance: An International Review, Journal of Accounting Literature, Accounting Horizons, Journal of Applied Business Research, the Financial Analysts Journal, and the Journal of Accounting, Ethics, and Public Policy. E-mail: john.neill@coba.acu.edu. Corresponding author.

O. Scott Stovall, Ph.D., is an associate professor of accounting at Abilene Christian University and has published articles in the Journal of Business Ethics, Corporate Governance: An International Review, Journal of Applied Business Research, Management Accounting Quarterly, and The Journal of Accounting Case Research. E-mail: stovallo@acu.edu

\section{REFERENCES}

1. Boyd, C., The Structural Origins of Conflicts of Interest in the Accounting Profession, Business Ethics Quarterly, Vol. 14, No. 3, pp. 377-398, 2004.

2. Bazerman, M., K. Morgan and G. Loewenstein, The Impossibility of Auditor Independence, Sloan Management Review, Vol. 38, No. 4, pp. 89-94, 1997.

3. Bazerman, M., D. Moore, P. Tetlock and L. Tanlu, Reports of Solving the Conflicts of Interest in Auditing Are Highly Exaggerated, Academy of Management Review, Vol. 31, No. 1, pp. 43-49, 2006. 
4. Damman, T., Audit: A Built-In Conflict of Interest, Corporate Board, Vol. 24, No. 138, pp. 16-22, 2003.

5. Davis, M., Conflict of Interest at Ethics Centers: A Primer, Working paper, Center for the Study of Ethics in the Professions, Illinois Institute of Technology, July 3, 2005.

6. Dilworth, J., The Ethical Importance of Conflicts of Interest: Accounting and Finance Examples, Business \& Professional Ethics Journal, Vol. 13, No. 1/2, pp. 25-40, 1994.

7. Hagerty, J. and N. Timiraos, For Lender, a Fast Fall From Audit to Collapse, The Wall Street Journal, August 28, 2009, M11 and online at WSJ.com.

8. Hoffman, W., J. Neill and O. Stovall, Mutual Fund Compliance Officer Independence and Corporate Governance, Corporate Governance: An International Review, Vol. 16, No. 1, pp. 52-60, 2008a.

9. Hoffman, W., J. Neill and O. Stovall, An Investigation of Ethics Officer Independence, Journal of Business Ethics, Vol. 78, No. 1/2, pp. 87-95, 2008b.

10. Moore, D., P. Tetlock, L. Tanlu and M. Bazerman, Conflicts of Interest and the Case of Auditor Independence: Moral Seduction and Strategic Issue Cycling, Academy of Management Review, Vol. 31, No. 1, pp. 10-29, 2006.

11. Nelson, M., Ameliorating Conflicts of Interest in Auditing: Effects of Recent Reforms on Auditors and Their Clients, Academy of Management Review, Vol. 31, No. 1, pp. 30-42, 2006. 


\section{NOTES}

